\title{
Hardness improvement on low carbon steel using pack carbonitriding method with holding time variation
}

\author{
Poppy Puspitasari ${ }^{1,3^{*}}$, Andoko Andoko ${ }^{1,3}$, Heru Suryanto ${ }^{1,3}$, Puput Risdanareni ${ }^{2}$, Sandy Yudha $^{1}$ \\ ${ }^{1}$ Mechanical Engineering Department, Engineering Faculty, Universitas Negeri Malang, 65145 Semarang, Malang, Indonesia \\ ${ }^{2}$ Civil Engineering Department, Engineering Faculty, Universitas Negeri Malang, 65145 Semarang, Malang, Indonesia \\ ${ }^{3}$ Centre of Nano Research and Advanced Material, Universitas Negeri Malang, 65145 Semarang, Malang, Indonesia
}

\begin{abstract}
Carbonitriding is a surface hardening process of steel by heating on critical temperature, quench and followed by tempering process. In this research, pack media in carbonitriding was used as a new method. Usually, this process has been obtained using gas and liquid carbonitriding methods. The specimen used in this research is low carbon steel (St. 41) consist of $0.1517 \%$ carbon, $0.1994 \%$ of silicon, $0.5631 \%$ of manganese, $0.0224 \%$ of phosphorus, and $0.047 \%$ of sulfur. Temperature for pack carbonitriding was at 700 ${ }^{\circ} \mathrm{C}, 750{ }^{\circ} \mathrm{C}$ and $800{ }^{\circ} \mathrm{C}$ and holding time variation 60 minutes and 120 minutes respectively. The result showed that carbonitriding temperature difference affect the mechanical properties of steel St. 41. Steel hardness was increased at lower holding time (60 minutes) compared to 120 minutes. The result showed that at $700{ }^{\circ} \mathrm{C}$ and $750{ }^{\circ} \mathrm{C}$ with 60 minutes variation, the steel hardness increase from $85.7 \mathrm{HRB}$ to $95.7 \mathrm{HRB}$ and at $800{ }^{\circ} \mathrm{C}$ the hardness decrease to $93.1 \mathrm{HRB}$. Meanwhile, at holding time of 120 minutes, steel hardness decrease from $94.1 \mathrm{HRB}$ to $92.7 \mathrm{HRB}$. This result caused by austenite phase produced at longer period of holding time.
\end{abstract}

\section{Introduction}

Surface hardening technique is a process to improve the properties of hardness and the performance of a component or material. Material damage usually starts from the flaw on the surface of the material due to the influence of environmental factors such as corrosion or wear due to the interaction with other components.

Various methods were used to improve the quality of the material surface, in accordance with the need of the desired product. Surface hardening technique commonly known as "surface treatment". Generally surface treatment can be obtained by two methods, first method is the addition of other chemical elements into the composition of the material (changing the chemical composition of the surface of a material), or it can also be achieved by the method of changing the phase or crystal structure contained in the material.

Some methods of surface treatment are nitriding, carburizing, carbonitriding, electric induction, and flame. Nitriding, carburizing and carbonitriding are surface treatment method by changing the surface properties with the addition of nitrogen or carbon into material properties. While the method of flame and electric induction is a surface treatment process by heating of material at a certain temperature followed by a rapid cooling process.

Carbonitriding is a steel surface hardening process on critical temperature by spraying gas. During carbonitriding process, carbon and nitrogen atom fused simultaneously into the steel by spraying gas media while the steel to the steel surface when it is heated.

Carbonitriding process is often referred as "Cyanide dry" [1]. It also known as modified form of gas carburizing, rather than a form of nitriding. The modification consists of introducing ammonia into the gas carburizing atmosphere to add nitrogen to the carburized case as it is being produced [4]. Carbonitriding process usually is used for increasing the hardness of low carbon steel surface, by heating it into carbon-nitrogen gas environment with lower temperature than carburizing temperature at 700 to $900{ }^{\circ} \mathrm{C}$, with a depth of layer about $0.7 \mathrm{~mm}$. Carbon and nitrogen-free which formed will be diffused into steel surface then react with ferrite or another alloy. Carbonitriding layer is more resistant than carburizing layer result against softening during tempering [2]. Some novel and tedious technique has been used such as plasma electrolytic carbonitriding $(\mathrm{PEC} / \mathrm{N})$ at ambient temperature and pressure and plasma electrolytic nitriding in glycerine and

\footnotetext{
${ }^{*}$ Corresponding author: poppy@um.ac.id
} 
acetamide solution [3].

Previous research showed that bone of cow can be used as a substitute for $\mathrm{BaCO}_{3}$ (Barium Carbonate) in solid carburizing process as alternative catalyst. The most rapid of carbon absorption rate occurs in a process by holding time for 25 minutes with the composition of $1 \mathrm{~kg}$ carbon (nani charcoal) and 30\% bone of cow that is $1.22 \mathrm{HRC} / \mathrm{min}$. Increasing the value of the largest average of hardness also occurs in the holding time for 25 minutes at $23.96 \%$ [5]

Previous research showed that charcoal with high carbon composition successfully used for carburizing media. Therefore, this research propose a new method of carbonitriding using charcoal and fertilizer with rich nitrogen as solid media. Type of fertilizer for this method is urea with more than $60 \%$ of nitrogen and charcoal from wood with more than $80 \%$ of carbon source. Holding time is varied to give sufficient time for carbon and nitrogen to enter the surface of steel. The reaction of carbonitriding consists of two main part:

The transfer of carbon from charcoal

$$
2 \mathrm{CO} \rightarrow \mathrm{C}+\mathrm{CO}_{2}
$$

The transfer of nitrogen from ammonia

$$
2 \mathrm{NH}_{3} \rightarrow 2 \mathrm{~N}+3 \mathrm{H}_{2}
$$

\section{Experimental details}

The experimental starts with specimen preparation using St. 41 Steel with $\%$ C $0.07 \%-0.1 \%$. The carbonitriding media consists of charcoal (coconut shell) and urea. The specimen was in cylinder shape and tied up with stainless steel wire in order to put inside the carbonitriding pack (Fig. 1). The specimen was placed inside the carbonitriding media consists of $50 \%$ charcoal and $50 \%$ urea in a pack stainless steel box. Stainless steel box has dimension of $20 \mathrm{~cm}$ (L) $\times 12 \mathrm{~cm}(\mathrm{~W}) \times 12 \mathrm{~cm}(\mathrm{H})$. Specimens was heated at $700{ }^{\circ} \mathrm{C}, 750{ }^{\circ} \mathrm{C}, 800{ }^{\circ} \mathrm{C}$ in muffle furnace and hold for 60 minutes and 120 minutes respectively. Specimens were then quenched in water for approximately 30 second and then cleaned for surface hardness testing using Rockwell Hardness Tester. The case depth analysis obtained by optical microscopy result. The measurement of case depth hardness was taken from the outer side of specimen (Fig. 2).

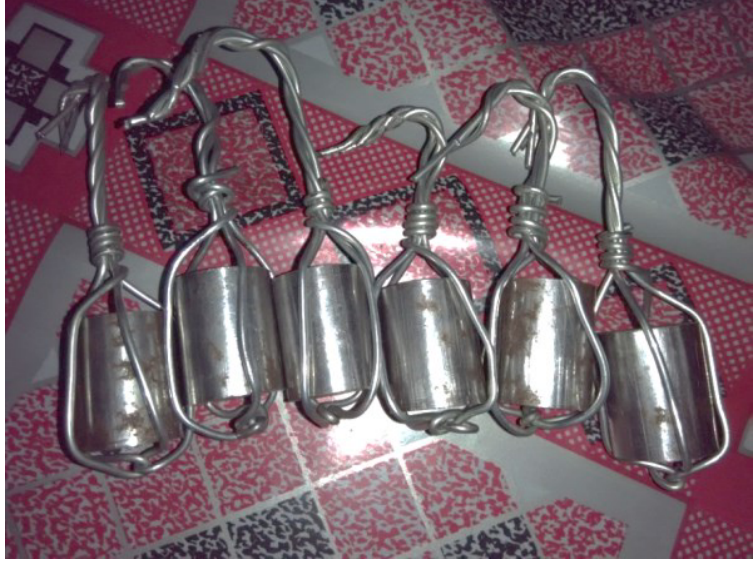

Fig. 1. Specimen of Carbonitrided Low Carbon Steel.

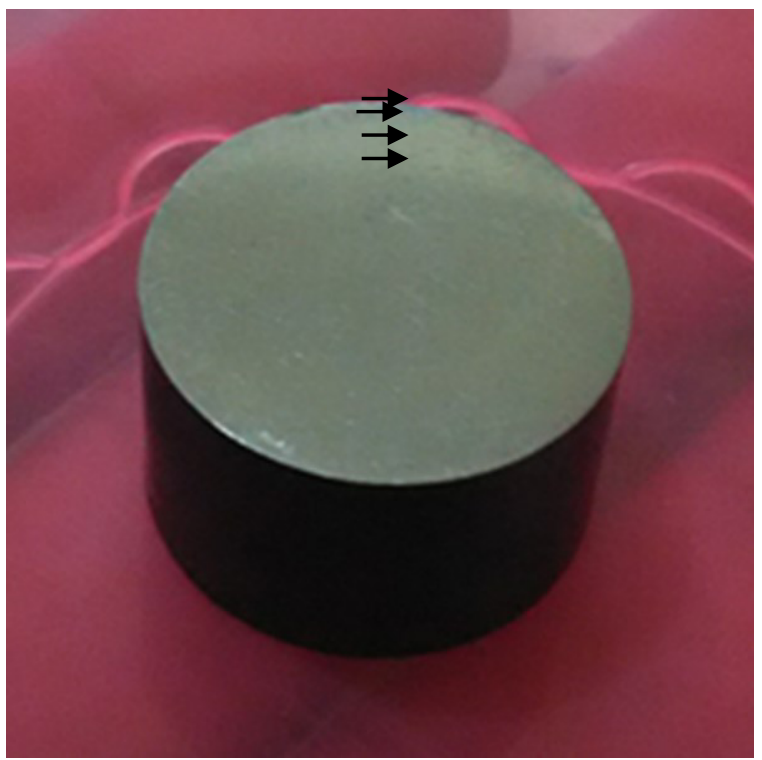

Fig. 2. Hardness Measurement from the Outer Side of Low Carbon Steel Specimen.

Chemical composition of low carbon steel was measured by X-Ray Fluorescense. The measured chemical composition of steel in this study is given in Table 1.

Table 1. Chemical composition of low carbon steel

\begin{tabular}{|c|c|}
\hline Element & $\mathrm{Wt} \%$ \\
\hline $\mathrm{Fe}$ & 99,0483 \\
\hline $\mathrm{C}$ & 0,09073 \\
\hline $\mathrm{Mn}$ & 0,48640 \\
\hline $\mathrm{P}$ & 0,01246 \\
\hline $\mathrm{S}$ & 0,02186 \\
\hline $\mathrm{Si}$ & 0,04448 \\
\hline $\mathrm{Cr}$ & 0,04218 \\
\hline $\mathrm{Cu}$ & 0,14905 \\
\hline $\mathrm{Ni}$ & 0,05200 \\
\hline $\mathrm{W}$ & 0,00754 \\
\hline $\mathrm{Mo}$ & 0,01744 \\
\hline \multicolumn{2}{|c}{} \\
\hline
\end{tabular}




\section{Results and discussion}

After the surface hardness data in carbonitriding process, the following step is calculating the mean value of hardness number in every carbonitriding process with temperature and time variation. Hardness investigation was taken from three different position as shown in Fig. 2. The results are summarized in Table 2.

Table 2. Hardness data of low carbon steel with carbonitriding method

\begin{tabular}{|c|c|c|c|c|}
\hline \multirow{2}{*}{ No } & \multirow{2}{*}{$\begin{array}{c}\text { Time } \\
\text { Variation } \\
\text { (minutes) }\end{array}$} & \multicolumn{3}{|c|}{$\begin{array}{c}\text { Rockwell Hardness Test } \\
\text { (HRB) }\end{array}$} \\
\cline { 3 - 5 } & $\mathbf{7 0 0}^{\circ} \mathbf{C}$ & $\mathbf{7 5 0}^{\circ} \mathbf{C}$ & $\mathbf{8 0 0}^{\circ} \mathbf{C}$ \\
\hline 1 & 60 & 85.7 & 93.1 & 95.7 \\
\hline 2 & 120 & 94.1 & 92.8 & 94.0 \\
\hline
\end{tabular}

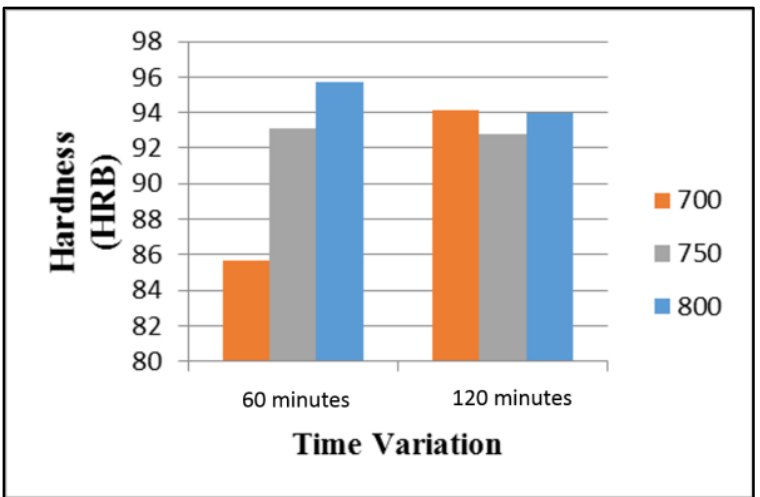

Fig. 3. Hardness value diagram in carbonitriding process time variation

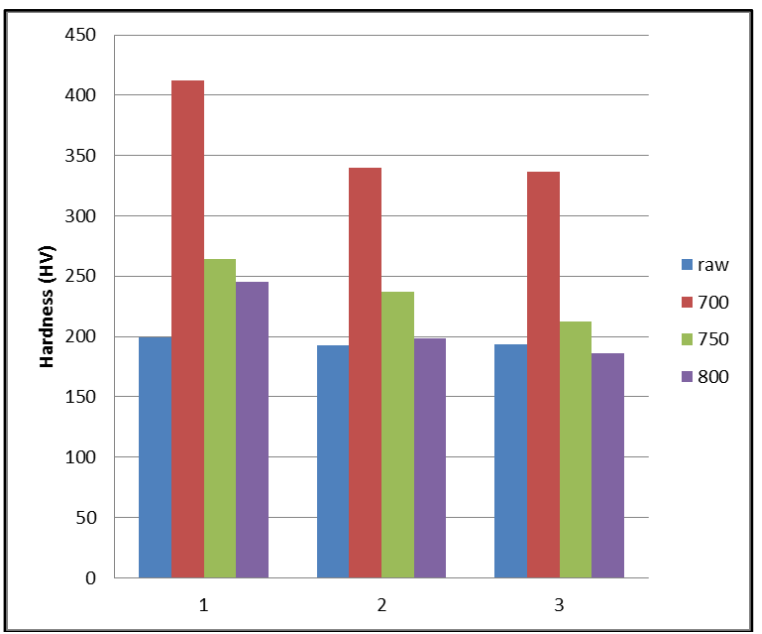

Fig. 4. Hardness value of low carbon steel in three different point

Difference hardness number after carbonitriding process as summarized in Table 1 state that, specimen I which has carbonitriding with HRB hardness difference temperature $=8.34$. On specimen II which has carbonitriding at temperature of $750{ }^{\circ} \mathrm{C}$ HRB hardness difference $=1.7$ and specimen III which has carbonitriding at temperature of $800{ }^{\circ} \mathrm{C}$
HRB hardness difference $=0.4$. Fig. 3. and Fig. 4 . Show the hardness value of specimen in the surface and three different point taken in each specimen. Hardness value decreased in second point and third point since the carbon depth did not reach the middle of specimen. It can be seen that the hardness of carbonitrided specimens are higher than raw material (non-carbonitrided specimen). This is possibly due to presence of carbides and nitrides uniformly in the fine martensitic microstructure. Carbides and nitrides were act as obstacle for dislocation motion which resulted the drop in hardness for carbonitrided specimens.

Carbonitriding process is one of carbon and nitrogen (ammonia) combination into steel surface. Addition of nitrogen on carburizing process turn it to carbonitriding process [6]. There were almost stabil hardness condition at 120 minute holding time because of the retained austenite that formed significantly under nitrogen influence. The amount of retained austenite will affect the value of hardness [7]. Hardness of specimen also affected from the formation of nitride in conjunction of nitrogen in urea. Nitride and carbide are the main phase that can increase the hardness in carbonitriding process [8-9].

Fig. 4 shows there is slightly decreas of hardness number in the depth of position from the surface. This is can be referred as transition zone which indicates the case depth of carbonitrided layer and this zone also related to microstructural stability [13].

\subsection{Microstructure thickness}

Carbonitriding process is one of carbon and nitrogen (ammonia) combination into steel surface. Addition of nitrogen on carburizing process turn it to carbonitriding process [6]. These are micro photo result of carbonitriding process with time holding and temperature variation.

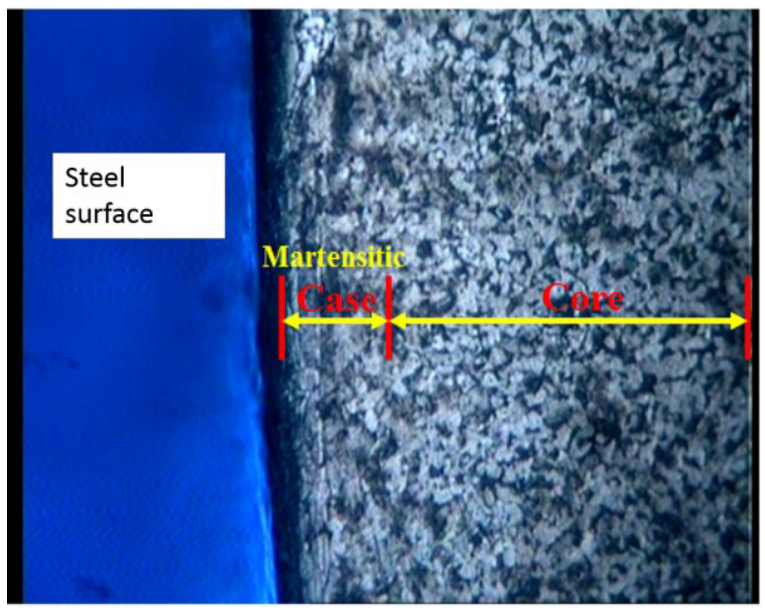

Fig. 5. Surface layer at $700{ }^{\circ} \mathrm{c}$ for 60 minutes. 


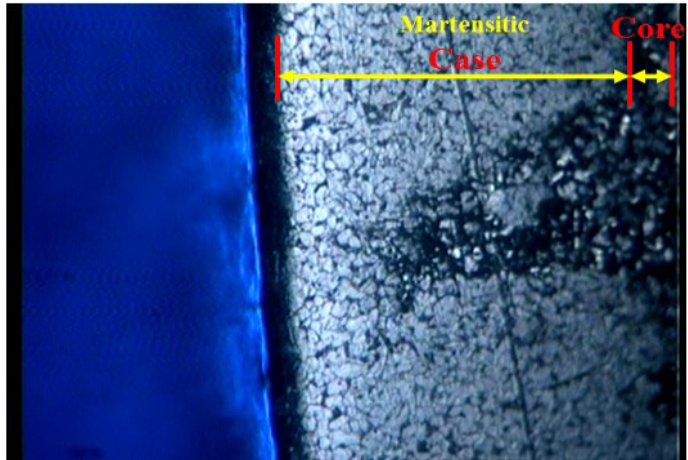

Fig .6..Surface layer at $700^{\circ} \mathrm{c}$ for 120 minutes.

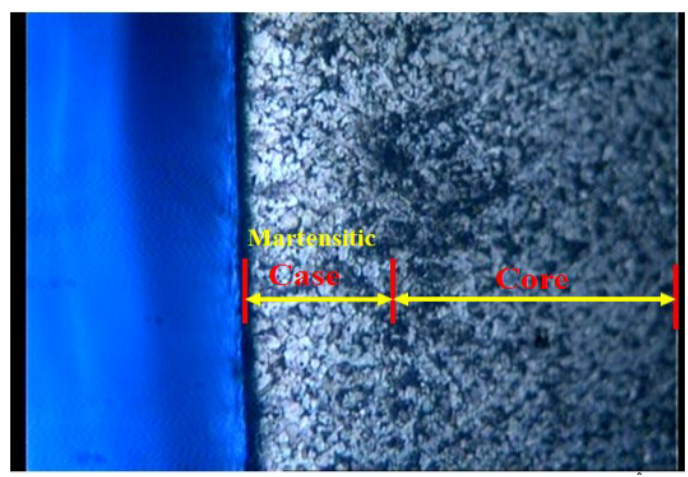

Fig. 7.Surface Layer at $750^{\circ} \mathrm{C}$ for 60 Minutes.

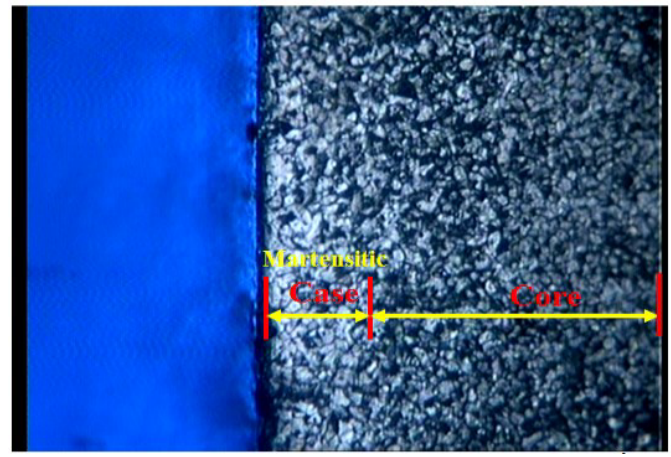

Fig. 8. Surface layer at $750{ }^{\circ} \mathrm{c}$ for 120 minutes.

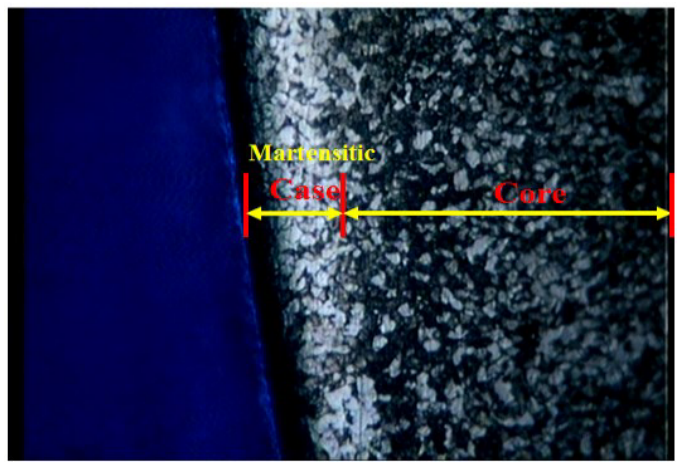

Fig. 9. Surface layer at $800{ }^{\circ} \mathrm{c}$ for 60 minutes.

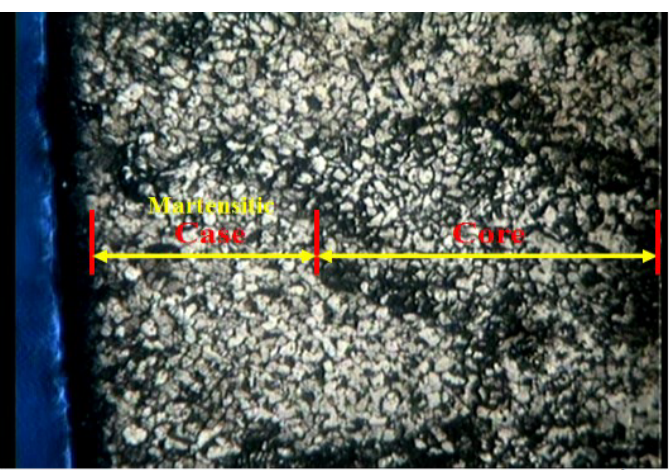

Fig 10. Surface layer at $800^{\circ} \mathrm{c}$ for 120 minutes.

It is obvious that carbon atoms contents at the surface are at the largest in the whole layer (Fig. 5Fig. 10). The thickness of the layer shows the significance increment as the carbonitriding temperature increased. The hardness number increase as the carbonitriding temperature increased, this is the reason that the higher temperature the carburizing is the main process with the presence of martensite phase. The phase transformation of the substrate at low temperature shows that nitriding process take place. The possibility of phase transformation is the presence of $\mathrm{Fe}_{3} \mathrm{C}, \mathrm{Fe}_{5} \mathrm{C}_{2}$, and $\mathrm{Fe}_{2}-3 \mathrm{~N}$ [3].

Carbonitriding process find in wide use in all branches industry e.g. in power engineering, car making, food industry, agricultural machines, etc. It was found as the best among hardening technologies [10]. Microstructure shows that there is formation of carbide, ferrite, and perlite. Fig. 11 shows carbide formation at grain boundary. At this condition, the carbide formation due to the absorption of carbon in carbonitriding process.

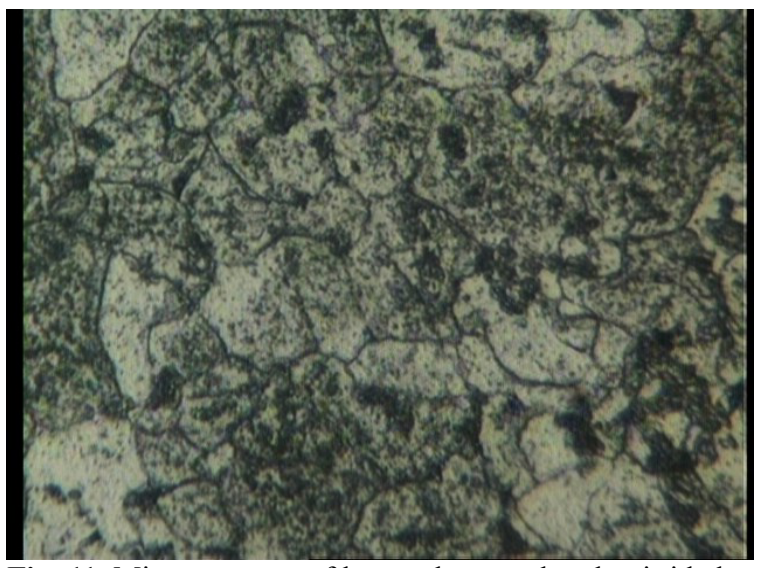

Fig. 11. Microstructure of low carbon steel carbonitrided at $700{ }^{\circ} \mathrm{c}$ 


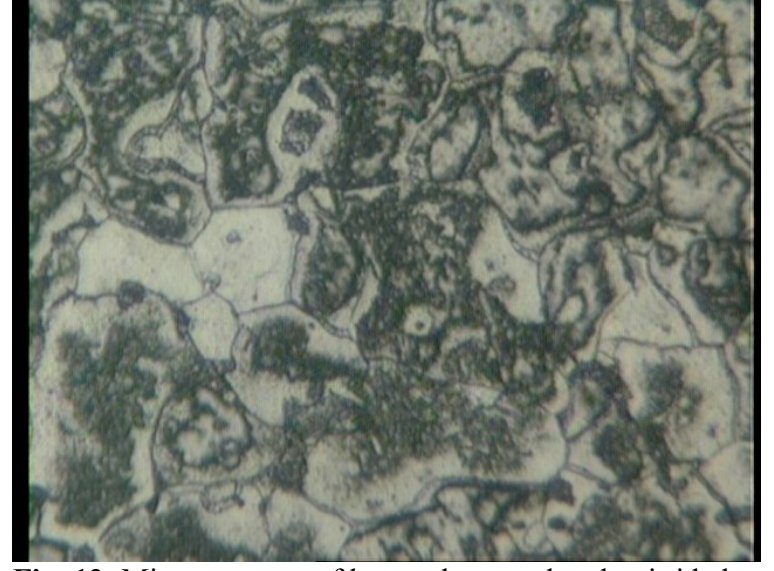

Fig. 12. Microstructure of low carbon steel carbonitrided at $750^{\circ} \mathrm{c}$

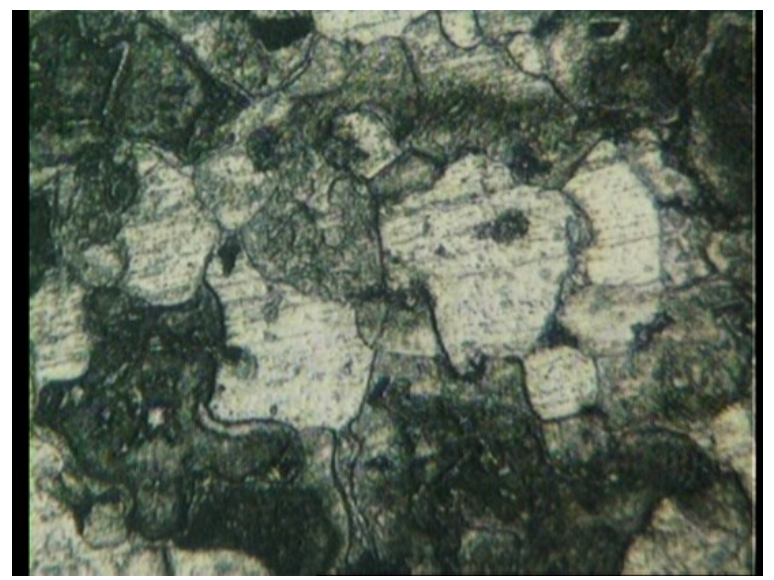

Fig. 13. Microstructure of low carbon steel carbonitrided at $800^{\circ} \mathrm{c}$

Fig. 12 and Fig. 13 show the carbide formation is not as clear as specimen at Fig 11. While the grain size become bigger and the carbide is not formed deeply into the middle of specimen. The core of specimens has ferrite-pearlite microstructure.

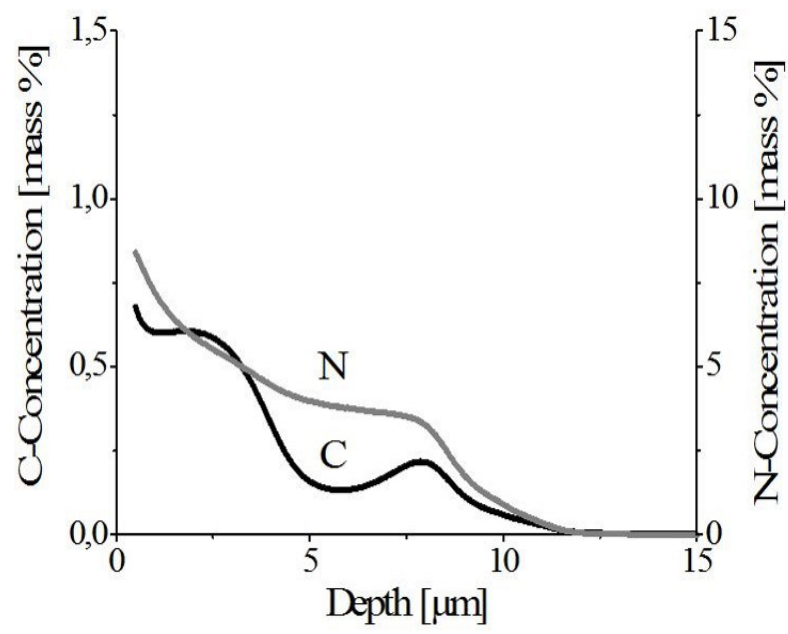

Fig. 14. Nitrogen and carbon profile analysis in depth of a layer from carbonitrided process in $550^{\circ} \mathrm{C}$ [11]
In carbonitriding process, the surface layer of the depth become larger in alloyed steel and this can be explained by total amount of nitrogen and carbon depth in Fig. 14. The prolongation of time in carbonitriding process will resulted the reducing carbon pressure and increasing ammonia pressure. This will increase total thickness, maximum hardness, bigger micro pores, and smallest residual compressive stress. [11]. Carbonitrided steel also has enhancement in life of component which was proved by comparison of ball bearing with and without carbonitriding process [12]. The precipitates of carbides and nitrides increases the stability of the microstructure, thereby increase the wear resistance [13].

\section{Conclusion}

The conclusion of this research is differences of low carbon steel surface microstructure which heated at temperature of $700{ }^{0} \mathrm{C}$ for 60 minutes and 120 minutes of holding time. The residual of austenite trapped simultaneously with carbon and the surface layer which has thicker of austenite start to diffused resulted increment in hardness number. While at temperature of $750{ }^{\circ} \mathrm{C}$ for 60 minutes of holding time, the residual of austenite trapped in lattice structure and for 120 minutes the nitrogen return into austenite phase formation stability. Therefore, the hardness decreases significantly. Specimen heated at temperature of $800{ }^{\circ} \mathrm{C}$ for 60 minutes of holding time showed the forming of austenite nitrogen in stable phase and for 120 minutes holding time resulted the surface layer decompose austenite properties on nitrogen which transform with ammonia properties.

I would like to express my gratitude to Universitas Negeri Malang for the support and opportunity to join this conference.

\section{References}

[1] J. A. Sukma, 2012, Pengerasan Permukaan Baja Karbon St 40 dengan Metode Nitridasi Dalam Larutan Kalium Nitrat, 25

[2] d.scribd.com/doc/187466082/PerlakuanPanas-Permukaan

[3] Pang Hua, LV Guo Hua, Chen Huan. Microstructure and Corrosion Performance of Carbonitriding Layer by Plasma Electrolytic Carbonitriding. China Physics Letter Vol 26, No. 8 (2009) 086805.

[4] Patiphan Juijerm. Surface Treatment Technology for Automotive Parts. Presented in Automotive Summet 2013, 20-21 June 2013, BITEC Bangkok, Thailand.

[5] Eka R.M.A. Lilipaly, Leslie Lopies, 2009, Analisis Nilai Kekerasan Baja S35C Dalam Proses Karburasi Padat 
[6] J. Slycke and T. Ericsson. 1981. A Study of Reactions Occurring During the Carbonitriding Process

[7] ASM Handbook Volume 4A. 2013

[8] Yudha, Sandy. 2015. Analisis Kekerasan dan Struktur Mikro Baja Karbon Rendah terhadap Variasi Waktu Penahanan pada Metode Carbonitriding. Malang: Universitas Negri Malang

[9] Suherman. 1988. Ilmu Logam 1. Institut Teknologi Sepuluh Nopember: Surabaya

[10] S.G. Tsikh, V.I. Grishin, A.V. Supov, V.N. Lisitskii, and Yu. A. Glebova. Advancement of the Process of Carbonitriding. Metal Science and Heat Treatment Vol. 52, No. 910, 2010.

[11] Zumbilev, Angel. Carbonitriding of Materials in Low Temperature Plasma. Technical University of Sofia-Plovdiv Branch, Bulgaria. Article in www. Intechopen.com (accessed at 31 December 2016).

[12] J.J.C. Hoo. Rolling Contact Fatigue Testing of Bearing Steels. ASTM Special Technical Publication, Philadelphia, 169-189. 1981.

[13] Rajan, Karthikeyan, Joshi, Vinod, Ghosh, Arindan. Effect of Carbonitriding on Endurance Life of Ball Bearing Produced from SAE 52100 Bearing Steels. Journal of Surface Engineered Materials and Advanced Technology. Vol. 3, 172-177. 2013. 